\title{
Empatian monet kasvot
}

Aaltola, Elisa \& Keto, Sami

Empatia - Myötäelämisen tiede

Into, Helsinki 2017

Eija Raatikainen

Empatia - Myötäelämisen tiede on dosentti (FT) Elisa Aaltolan ja tutkija tuu kahdesta osasta - kirjoittajien omista osioista. Kirjan ensimmäinen osa käsittelee empatian eri muotoja ja niiden suhdetta moraaliin. Empatiaa valotetaan moraalifilosofian keinoin. Toisen osan huomio kiinnittyy empatian yhteiskunnalliseen rooliin tarkastellen sen evoluutiotaustaa sekä esiintymistä ihmis- ja eläinyhteisöissä.

Empatia on viime vuosina noussut aikaisempaa vahvemmin esille. Myös sille läheinen myötätunto on saanut huomiota. Positiivisen psykologian vahvistuminen on kiinnittänyt huomiotamme entistä enemmän ihmistä vahvistaviin ja onnellisuutta lisääviin tekijöihin. Aaltolan ja Kedon teos ei kuitenkaan kuulu tähän suuntaukseen, vaan kirjoittajien ote on vahvasti yhteiskunnallinen, filosofinen ja ekologinen. Kirjan kannessa oleva kuva aivoista muistuttaa lukijaa empatian neurologisesta perustasta.

Empatian tutkiminen on muutakin kuin ensisilmäyksellä voisi ajatella - se perustuu fysiologisiin tosiasioihin: hormoneihin, peilisoluihin ja hermoston toimintaan. Teos tuo tarkasti esille monien esimerkkien kautta empatian yhteiskunnallisen ja yhteisöä ylläpitävän voiman. Kirja on kriittinen ja syvällinen esitys empatian moninaisuudesta. Siitä kertovat myös teoksen oivalliset otsikoinnit, kuten Projektiivinen ja simuloiva empatia, Kognitiivinen-, Affektiivinen-, Ruumiillinen- ja Reflektiivinen empatia, Empatian ongelmat, Empatia yhteiskunnassa, Kuka minä olen - Eli miten empatia sopii kertomukseen yksilöstä, tai Mihin jengiin kuulut? - Eli miten 
sosiaalisuutemme rajat vaikuttavat empatian piirimme laajuuteen. Yksittäisenä alaotsikkona uteliaisuutta herättävät myös otsikot Hormoniyhteiskunta, Testosteronimarkkinat tai Kohti empaattisempaa minäkuvaa. Empatiaa valotetaan kirjassa lähes 400 sivun verran.

Teoksen johdannossa avataan ansiokkaasti se, mitä empatialla tarkoitetaan. Kirjoittajat kuvaavat empatian olevan "kyky ymmärtää, sekä parhaimmillaan myötäelää muiden ihmisten kokemuksia. Empatia auttaa hahmottamaan muiden näkökulmaa ja kokemuskenttää ja saa meidät välittämään heidän hyvinvoinnistaan. Empatia paljastaa kärsimystä, onnellisuutta ja kaikkea siltä väliltä, ja juuri tämä herättää myös moraalista huolta" (s. 7). Empatia lanseerattiin käsitteenä 1800-luvun lopussa, viitaten lähinnä esteettiseen kokemukseen, jonka puitteissa katsoja identifioitui taiteen synnyttämään tunteeseen. Tuolloin empatia katosi (tuolloin jo pidemmän aikaa esillä olleen) sympatia-käsitteen "alle".

Kirjan alkuosa on vahvan filosofinen ja yhteiskuntahistoriaan juurtuva. Luvussa määritellään kognitiivinen, affektiivinen ja ruumiillinen empatia. Kognitiivinen empatia on sitä, että ihmisien havaitsee ja päättelee muiden tunnetiloja, harjoittaa mielenluentaa, kun taas affektiivinen empatia voidaan määrittää empatian tunnejakamisen tilaksi. Ruumiillinen empatia eroaa muista empatian lajeista siinä, että se ei keskity pelkästään havaintoon ja järkeilyyn vaan myös kehollisuuteen.

Teoksessa tuodaan jo melko alkuvaiheessa raikkaan yllättävästikin esille usein populaariuutisoinnissakin esillä olleet psykopatia ja narsismi suhteessa empatiaan (s. 52, "Empatian pimeä puoli"). Empatian pimeällä puolella viitataan siihen, että ihmisen korkea kognitiivinen empatia mahdollistaa hänelle tarkkaa muiden mielenlukemista tunnetason ja huolentunteen puuttuessa. Tällöin vaarana voi olla se, että ihminen hyväksikäyttää saatua tietoa palvelemaan egoistisesti omaa etuaan. Ilmiötä valotetaan historian avulla, luoden sille syvempi historiallinen konteksti kuin tavallisesti. Teksti on vahvaa ja vakuuttavaa ja vaatii enemmän aikaa kuin tavanomainen kyseisestä aiheesta kirjoittelu. Vastaavasti perustelut ovat vakuuttavampia ja mieleen jää ilmiöistä laajempi muistijälki.

Kirjan ensimmäisessä osassa Aaltola kuljettaa empatiaa tunteiden ja järjen suhteen välisenä teemana tuoden esille rationalismin ja moraalin suhdetta empatiaan. Hän valottaa teemaa monien ajattelijoiden kautta (Kant, Hume, Schopenhauer, Nussbaum). Empatia moraalisena pohdintana on sivistävää luettavaa. Aaltolan ajatukset moraalista (s. 19) ja toissuuntautuneisuudesta eli siitä, että otamme tilanteissa huomioon muiden 
näkökulman ja hyvinvoinnin, tulevat lähelle sosiaalipedagogista ajattelua. Aaltola kohdentaa katsetta empatian eri muotoihin ja lajeihin. Hän kirjoittaa: "Empatialla on liuta erilaisia muotoja, joilla voi olla rajusti eriäviä moraalisia seurauksia - tämä osoittaa empatian tarkastelun tässä kirjassa kiinnostavana, silloinkin kuin siitä ei ole meille hyötyä’. Empatiaa tarkastellaan myös eläinten osalta. Tämä on pysähdyttävää luettavaa.

Aaltola tuo esille myös yleisesti käytetyn käsitteen "myötätuntoväsymys", tosin korvaten sen "empatiaväsymyksellä". Jään pohtimaan, miksi käsite on korvattu. Teos olisi kestänyt myös myötätuntoväsymyksen käsitteen käytön, heikentämättä sen yhteyttä empatiaan. Kirjassa ehdotetaan keinoksi empatiaväsymyksen välttämiseen toimimista muiden hyväksi toivoa luoden. Kaikkinensa aiheesta olisi ollut mielenkiintoista lukea enemmänkin.

Myös Keto osoittaa teoksen toisessa osassa, että empatia on moniuloitteisempi ilmiö kuin ensi alkuun voisi ajatella. Toinen osa tuo esille ajankohtaista yhteiskunnallista analyysia, ensimmäisen osan painottuessa empatian filosofiseen tarkasteluun. Osat täydentävät toisiaan. Kedon tarkkanäköinen analyysi vakuuttaa lukijan empatian biologisesta perustasta. Kirjan takakannessa kuvataan Keto ekologiksi, joka on aikaisemmin toiminut ympäristönsuojelun parissa. Kirjoittajan tausta heijastuu kirjoittamisen tapaan. Uusia ovia empatian tarkasteluun avautuu.

Toisen osan alussa valotetaan geenien, hormonien ja aivojen välittäjäaineiden osuutta empatiassa. On kiinnostavaa lukea neurotieteilijöiden tuloksia hormonien ja empatian välisestä suhteesta. Osoittautuu, että testosteronilla saattaa olla kielteinen vaikutus empatiaan, koska sen on havaittu vaikuttavan luottamusta alentavasti, erityisesti, jos ympäristö koetaan uhkaavana (s. 173). On pohdittava, miten kirjassa esille tuotu tutkimustulos siitä, että ihmisen testosteronitaso vaikuttaa empatiaa alentavasti, sopii tasa-arvoa etsivään yhteiskuntaan. Herää kysymys, hyväksytäänkö tämä tosiasiana, vai "yritetäänkö entistä enemmän luoda toisten huomioimista arvostavaa yhteisöä, joka puolestaan on kirjoittajan esittämän tutkimuksen mukaan tekijä jolloin testosteroni voi ohjata myös prososiaaliseen toimintaan. Hormonit ja välittäjäaineet voivat vahvistaa empatian kannalta joko positiivista kehää tai siitä kauemmaksi vievää noidankehää.” (s. 174.)

Kaiken kaikkiaan kirjan toinen osa tuo onnistuneesti esille empatian moninaisuutta ajankohtaisten esimerkkien avulla. Kirjan haasteeksi osoittautuu lukujen välinen suhde, ja se vaatii lukijalta taitoa palata otsikkoihin asiayhteyksien ja kokonaisuuksien hahmottamiseksi. 


\section{Lopuksi}

Sosiaalipedagogiikan ydin on sosiaalisen ja kasvatuksen suhteessa, mahdollisuudessa tukea ihmistä hänen hyvinvoinnissaan ja liittymisessään yhteisöihin ja yhteiskuntaan - tukea olemaan osallinen. Empatiaa voidaan pitää mitä keskeisimpänä tekijänä kohtaamisissa, joissa osallisuus mahdollistetaan. Rakenteista huolimatta ihmiset lopulta rakentavat, ylläpitävät tai tuhoavat yhteisön tai yhteiskunnan. Ilman empatiaa, liittyminen ja kiinnittyminen olisivat haasteellisia. Sosiaalipedagogisesti ajateltuna empatiaa voidaan lähestyä kirjoittajien tavoin siten, että empatiaa pidetään "elämänasenteena ja kokonaisvaltaisena tapana suhtautua toisiin ihmisiin" (s. 265). Tällöin se kutsuu pohtimaan empatiaa ilmiönä laajemmin. Mitä voisi tarkoittaa sosiaalipedagogisesti virittynyt empatia? Voisiko se käsittää laajasti empatian havainnoinnin, tunnistamisen, tunnustamisen, siihen kannustamisen, olemisen, tietämisen ja toimisen tasot - tavoitteena toivon, uskon ja luottamuksen luominen.

Hyvällä syyllä voi myös kysyä, voisiko empatia toimia sosiaalipedaogogisen työotteen ytimenä siten, että sen avulla voisimme "ymmärtää myös tyyneyttä, tyytyväisyyttä, rakkautta ja iloa", kuten Aaltola ja Keto empatiasta toteavat. Voisiko se toimia kanavana "toivon herättämiseen, ja näkemään maailmassa hyvää ja optimismia”, kuten Aaltola ja Keto myös ehdottavat. Voisiko empatian avulla herättää yhdessä toisten ihmisten kanssa uusia, toivorikkaampia ja oikeudenmukaisempia tulevaisuuskuvia? Tämän pohtimiseen Aaltolan ja Kedon teos Empatia - Myötäelämisen tiede tarjoaa erinomaisia aineksia. Kirjan jälkisanoissa nousee myös esille ajatus, jonka mukaan "empatia voikin olla tapa opettaa muille lempeämpää olemassaoloa - sellaista, jossa syytösten sijaan sykkii armollisuus" se on mielestäni on erinomainen kiteytys empatiasta - ja sopii hyvin myös sosiaalipedagogiseen viitekehykseen.

Empatia-kirja on mitä loistavin teos laajalle lukijakunnalle alasta riippumatta. Se sopii yhtä hyvin lääkäreille, keskijohdolle kuin sosiaalipedagogiseen työhön siirtyvälle vastavalmistuneelle opiskelijalle. Se sopii kenelle tahansa, joka on valmis pysähtymään ennakkoluulottomasti ja keskittyen laajan ilmiön äärelle. Empatia ei ole enää koskaan entisensä lukukokemuksen jälkeen! Kaiken kaikkiaan kirjan anti on runsas, ja siitä olisi saanut helposti kaksikin teosta. Esimerkiksi oppikirja empatiasta sosiaalipedagogisena työotteena voisi olla kiinnostavaa soveltavaa lisälukemista. 